\title{
CHINA, THE CENTRAL ASIAN REPUBLICS, RUSSIA, AND MONGOLIA
}

\section{By Eric A. MeVadon, Rear Admiral, U.S. Navy (Retired)}

Summarizing Beijing's Proclamations on Regional Security I want to begin our session today with some of my thoughts on the security situation among China, the Central Asian Republics, Russia, and Mongolia. I will start with a look at Beijing's stated overall approach to regional security relations as the new century begins. I emphasize that these are my interpretations of Beijing's statements, which might be summarized as follows:

( Beijing is increasingly attentive to its peripheral environment, primarily because China needs regional stability to continue national economic development, truly China's top priority and the one thing of which China can truly be proud.) (There is more effective, but gentler, assertion of China's role as a preeminent power in the Asia-Pacific region, and as the appropriate permanent pillar of regional stability; Asians solving Asia's problems, not Westerners.) (China's leaders pursue the conviction that their national power is primarily a function of economic development rather than military capabilities, and we see good evidence that this is in fact the case.)

(There is in China a new and somewhat surprising acceptance of, even a budding preference for, use of multilateral means and international law to settle disputes, but a hardening of opposition to alliances.)

This is the picture painted by Beijing's own brush strokes, some meant to be seen by the world and others a consequence of China's habit and style. It is a picture at variance with Beijing's traditional bullying and blustering behavior toward its neighbors. It is a very different context from that which many might anticipate as China's approach to security relations with its neighboring states in the coming years. It is, of course, not possible to forecast with confidence how Beijing will proceed. However, we can examine whether China's actions seem to match its words. A cautionary note is in order at this juncture, however. Neither China's 1998 Defense White Paper nor other Chinese statements and actions, official or otherwise, suggest that the TAIWAN problem can be pursued along the lines suggested above for handling regional security relationships and resolving disputes with neighboring countries. Similarly, Beijing would not, of course, consider that matters of contention concerning Tibet, Xinjiang, or Inner Mongolia would fall within the rubric of disputes Between China and 
neighboring countries. Beijing sees all these as internal matters, about which its attitudes have changed very little, if at all, and for which significant change is not now foreseen.

\section{The View into West Turkestan}

When thinking of China's neighboring states, Westerners often tend to think last, if at all, about the countries of the former Soviet Union that lie to the northwest of China, the newly independent nations of Central Asia bordering China's restive Xinjiang Uighur Autonomous Region. Xinjiang has been, and remains, a hotbed of anti-Beijing unrest, especially in recent years. This Muslim dissent is fueled by exacerbating factors such as the conspicuous transition to independence of the Turkic Central Asian nations, the rise in the region of Islamic fundamentalism, and unhappiness with Beijing's domestic policies for the autonomous region, one of five such regions in China. In addition to the very large and aggravating influx of ethnic Han Chinese, for which Beijing is sharply criticized, Uighurs feel that other Chinese policies or failures to act are keeping them in poverty. The Hans are perceived as reaping most of the benefits of exploitation of Xinjiang's considerable natural resources and profiting from the growing economic links with the neighboring countries. Beijing's poverty eradication measures are viewed with disdain and considered a meager, token effort.

Bombings, rioting, and assassinations by separatists have been met by Beijing with police raids, very large-scale arrests, and numerous executions of Uighurs - all in an attempt to curb terrorist actions and crush the independence movement. Some of the Uighur terrorist incidents and killings were provocatively timed to coincide with the funeral in February of 1997 of former paramount leader Deng Xiaoping and the visit to China in June and July of 1998 by U.S. President Clinton. Reports of the frequent killing by separatists of police in cities near the borders continue. Stringent security measures have been instituted to prevent further unrest and have even spread to western Beijing where thousands of Uighurs lives. We are striking hard every day, each season, all year, leaving ethnic separatists and terrorists no room to breathe, said Chen Zhuangwei, chief of police in the province's Kashgar region early this year. Support for the dissidents in various forms from the neighboring countries is significant. Kazakh activists have accused Beijing of persistent human rights violations in Xinjiang and of repressing their fellow Uighurs. A pro-separatist organization in Kazakhstan named the United National Revolutionary Front 
calls for the removal of Han Chinese from Xinjiang and the establishment of an independent Islamic Republic of East Turkestan. Beijing feels that moral support, sanctuary, and arms have been provided by sympathizers in the bordering Central Asian countries. Separatists supported in this way are seen by Chinese leaders as menacingly, and increasingly, well armed and financed. Despite its heavy-handed security and military actions within Xinjiang, China has met the threat from Kazakhstan and its Central Asian neighbors with a diplomatic and economic offensive. In April 1996 in Shanghai President Jiang Zemin signed an agreement with Russia, Kazakhstan, Kyrgyzstan, and Tajikistan on security and confidence-building measures on their borders. The (significantly) multilateral agreement is designed to reduce border tensions (although no clashes had occurred in some years) but also serves to make clear to Washington the nature and range of Beijing's options and influence. The three Central Asian states signed the agreement despite protests by the Uighur minorities in their countries. These opponents argue that China is trying to obliterate or neutralize Uighurs in Xinjiang. The specific provisions of the treaty require the parties to inform each other about military exercises within 100 kilometers of the borders, ban military exercises directed toward another party, and state that military forces of the five states will not attack one another. The treaty, it should be noted, also serves to establish solid links between Beijing and the Central Asian capitals for cooperation in quelling cross-border Higher dissent. A year after that agreement, in April 1997, following serious unrest in Xingjian in February of that year, the presidents of these five countries concluded another treaty, this one signed in Moscow. It provides for troop reductions on China's borders with these countries of the former Soviet Union. The pact limits forces within 100 kilometers of the borders and provides for mutual inspection. Several months later, as unrest in Xinjiang simmered, China and Kazakhstan signed a $\$ 9.5$ billion oil and pipeline deal. The arrangement was evaluated by Western specialists as economically infeasible. Beijing, however, was undeterred by this projection. China's sole purpose was not development of oil fields and pipelines; the Chinese economic offensive also had as its target fostering Kazakh cooperation in curbing Uighur separatist efforts and other Muslim dissent.

More recently, in July 1998, the group of five, as the gathering of the five countries was called informally, met in Almaty and agreed to collaborate on fighting organized crime and political separatism. On the margins of that meeting, Chinese President Jiang and Kazakh President Nazarbayev signed an agreement settling border disputes, described as the final document concerning bor- 
ders between the two countries. The resolution reportedly slightly favored the smaller country, with Kazakhstan gaining undisputed possession of 53 percent of the disputed areas. Possibly of greater consequence was agreement between Jiang and Nazarbayev to develop a 15 -year economic program including a proposed automobile plant in Kazakhstan, electrical transmission arrangements, Chinese investment in the country, and construction work by China in the new capital. Also of significance, was further confirmation by the two leaders of the September 1997 oil production and transport deal, although Western executives continued to express doubts about the viability of the proposal? These several diplomatic and economic undertakings by Beijing suggest that in this pesky situation China is far more ready to employ military force within its borders than without. This seems to be the case although the small countries involved would not likely be able to repel a PLA force dispatched to assist in crushing the Uighur movement in Kazakhstan, for example. Certainly, there are many good reasons for Beijing to refrain from the use of force in such situations with a neighbor. However, its readiness to employ force in 1962 against India, in 1979 in Vietnam, and on other occasions against Vietnam in the South China Sea cannot be ignored in contemplating which options Beijing is prone to select. It appears there was not even the threat, direct or implied, of the use of the PLA in the difficulties, which spanned a number of years and included jeopardy to Chinese sovereignty of Xinjiang and efforts to embarrass Beijing on the world scene. Remember, for example, the coincidence of terrorist efforts with the funeral of Deng and the visit of Clinton, as I mentioned.

Beijing has, instead, cast its lot in the direction of cooperative arrangements with these comparatively tiny neighbors. It is hard to determine if the decisions to conclude border agreements were contrived as a vehicle to cement bonds with, the Central Asian states or if they propitiously occurred. In any event, Beijing took full advantage of these agreements and then went so far as to hold out the promise of sweeping economic ties. Consequently, it seems the most likely role at the beginning of the next century for the PLA in this troublesome region for China will be to back up the People's Armed Police and the Public Security Bureau forces in their activities to curb dissent within Xinjiang.

These economic rather than military initiatives by China are viewed very positively in the West. We like to see China giving less emphasis to the PLA and more emphasis to economic security measures. I ask of you, however, whether these developments make Mongolia comfortable or whether you are more concerned about the economic threat from China than the threat of military force. 


\section{Looking Northward to Russia: Strategic Partner or Potential Threat?}

I want now to turn to China and Russia. In April 1996, China and Russia unveiled what they termed a strategic partnership for the future. On that occasion in Shanghai, President Jiang said, CHINA is not posing, and will not pose in the future, any threat to Russia. President Yeltsin, with customary unbridled enthusiasm, said, / views the Sino-Russian partnership...as a model for relations between two countries. I can't name a single question on which we would have different opinions. Near the end of 1997, both Moscow and Beijing reportedly described the Sino-Russian relationship more fully as constructive cooperation aimed at strategic partnership in the twenty-first century.

Regardless of the precise wording of the description of the bilateral arrangement, its mere existence reveals at the very least a desire in Beijing and Moscow to demonstrate to Washington and others considerable confidence that the bilateral relationship is on a firm footing for the future. But it is interesting to take a closer look at this relationship between giants. At the end of the 1980s, when then-President Gorbachev visited a China on the brink of the Tiananmen Square debacle, the Soviet Union was coasting economically, and the Communist Party there seemed to have found a way to achieve reform and remain viable. Now, the situation is quite different. With Russia now politically and economically deeply troubled, China is the one that can gloat over the status of its economy and a Party that has stayed in power through a time of great change in Chinese society. China smoothly effected the transition of national presidents (Yang to Jiang) and, more recently, premiers (from Li to Zhu). Russia tumultuously went from President Gorbachev to President Yeltsin and, with respect to prime ministers, has made changes more often than Italy. It is now the lot of Russian leaders to be envious.

The economic victors and vanquished. Another very pertinent aspect of these events, not lost on Chinese leaders, is that national economic developments, not comparative military prowess, have been instrumental in the reversal of roles between China and Russia. The change in the military condition has been an indirect consequence of economic and political developments in both countries. The contrast between the countries could hardly be starker: Russia's economic crisis deepens and China, even with weakening economic growth prospects, seems to be weathering the Asian financial crisis better by far than almost all its neighbors. China has achieved a secure relationship, even something that can be termed a strategic partnership, almost altogether through its national economic progress. All the while, the bested partner, Russia, is be- 
nignly cooperating with China in challenging the U.S. role in the region. Many in Beijing must feel that they have succeeded masterfully in subduing the Russian bear and that China can feel much more secure when it looks northward.

America bashing. Challenging the United States is another important aspect of the solidarity between Beijing and Moscow that has enhanced the partnership. The bilateral bonds have been strengthened by the perception of having a common adversary in a battle that matters. Both capitals have taken great satisfaction in directing barbs at Washington. In December of 1996, Premier Li Peng and President Yeltsin candidly vowed to forge closer military and economic ties to counter the influence of the U.S. in the post-Cold War world. Washington is characterized by these partners as coveting its superpower status in a univocal world, clinging to Cold War thinking, and pursuing confrontation in its relations with China, while Beijing and Moscow purportedly show the world a new model for peaceful relationships. The April 1997 China-Russia joint statement on the bilateral arrangement expresses grandly that the purpose of the partnership is to promote the multi polarization of the world and the establishment of a new world order. With evident reference to the U.S., it explains, THE establishment of a just and equitable new international political and economic order based on peace and stability has become the pressing need of the times and the inevitable necessity of history. No country should seek hegemony, practice power politics, or monopolize international affairs.

With respect to political aspects of the partnership, Beijing supported Moscow's early, if unfocused, opposition to the eastward expansion of NATO. The April 1997 statement said:

Both sides stand for the establishment of a new and universally applicable security concept, believing that the Cold War mentality must be abandoned and bloc politics opposed.

The differences or disputes between states must be settled through peaceful means without resorting to the use or threat of force. Dialogue and consultation should be pursued to promote mutual understanding and build confidence, and peace and security should be sought through coordination and cooperation at bilateral or multilateral levels. Returning the political favor, Moscow offered its confirmation that both Tibet and Taiwan are inseparable parts of China. The Russian Defense Minister reportedly went so far in an April 1997 speech in Beijing at the Academy of Military Sciences as to express readiness to support China in an armed conflict on the Korean Peninsula support I think China may not welcome. He blamed the potential for conflict there on alliance arrangements 
and said, RUSSIA will not be able to remain aloof.

The roots of partnership. In Russia, China has cultivated an excellent partner for its entry into the future: partly Asian, until recently communist, residually authoritarian, presently non-threatening, and ready to criticize and even challenge Washington. The question is whether this marriage is one of temporal convenience or whether there are enduring qualities in the relationship that will, in fact, cause it to overcome difficulties and endure into the next century. Already, the amount of attention given by Beijing and Moscow to touting the partnership seems to have waned significantly.

The role of arms and technology transfers. There is, however, one area of unquestioned substance and apparent durability in the relationship: arms sales and military technology transfer. This cooperation significantly pre-dates the 1996 formation of the partnership. Russian Deputy Foreign Minister Aleksandr Panov said three months before the partnership was announced that connections with the PLA and cooperation on armaments manufacture are being developed and will be developed. He went on to note the importance of China as a market for the stumbling Russian arms industry. He described Russia's goal under the five-year military cooperation agreement it signed with China in 1993 as to promote the sale of Russian military equipment without upsetting the military balance in the region.

Although arms sales and military technology transfer seem clearly to be the most active and conspicuous aspect of the strategic partnership, problems remain in that area. Since the mid-1990s, Moscow has pressed Beijing hard for payment in hard currency rather than largely in barter as had been the

Case prior to about 1994. Allegedly in 1994 Beijing and Moscow signed an agreement to transition to payments in hard currency. The degree of success of that arrangement is not yet clear to outsiders. However, information from various sources seems to confirm that price, form of payment and financing methods remain troublesome.

Russia's deepening financial crisis is an additional complicating factor. China, in coming years, will be no less inclined to seek favorable terms, but Russian officials are not likely to become any more generous, and, of course, may well make greater demands with respect to payments in hard currency and normal financing terms. On the other hand, Russian arms industries will likely become more desperate for markets abroad. Russian research scientists, technicians, and others with specialized knowledge of value to the PLA and China's defense industries will be more inclined to accept paying work in China, tempo- 
rarily or permanently. Regional neighbors and others, including the United States, will have heightened concerns. However, unlike earlier decades, both Moscow and China will take those concerns into account in decisions about arms sales and technology transfers.

All these factors will introduce strains into the Sino-Russian military cooperative arrangements. One cannot help but wonder, in light of these factors, about how Beijing views the military supply relationship. Does Russia appear reliable, in the eyes of the PLA leadership, as a supplier of technology and weapons and all the associated support in the form of long-term training, maintenance assistance, spare parts, etc.? The PLA has sound grounds for at least some measure of concern. It was badly burned by the dissolution of the arms and technology transfer relationship with the Soviets around 1960. The PLA was emphatically reminded of that peril again in 1989 through the imposition of sanctions by the Americans after its Tiananmen Square intervention rupturing a budding military supply and technology transfer relationship of potentially great value to the PLA. From a broader perspective, it simply cannot be assumed that the flow of arms from Russia to China will remain a major feature of their bilateral relationship. It is highly likely, but hardly assured. What does all this portend for security relations in the twenty-first century between the world's largest nation and most populous nation? Regardless of whether their strategic partnership truly takes on the mantle of a universal security concept that would promote world peace, as Xinhua has termed it, the most pertinent aspect is what this partnership means for Sino-Russian bilateral relations and the effects that has on regional security. In the early 1990s, one could not go very long in discussion with Chinese security specialists without hearing about the potential threat from a reawakening Russian bear. Now, in place of fears of Russian unpredictability, much is heard about equality and trust in the relationship. Admittedly, the tone and frequency of such pronouncements give reason to wonder about whether these are really more hopes for the relationship than descriptions of its status. Does Beijing truly see Moscow as a regional security partner in Asia? Or is Russia really perceived as primarily a European interloper looking to protect from the Chinese hordes its troubled expanses of Siberia and the corrupt and unstable Russian Far East? Or is Moscow, for the most part, simply a convenient partner to challenge Washington and its alliances at a time in history when China's other neighbors is not inclined to do so? There are, of course, no ready answers to these questions, but this is one of those situations where knowing the questions is of considerable value to us. 


\section{A New Security Architecture and Mongolia}

There are other questions we should ask at this point. When there is change on the Korean Peninsula, whatever form that takes and whenever it occurs, what will be the new or evolving security architecture for Northeast Asia, and what should Mongolia's role be? There will be conflict between Washington's strong desires to keep its bilateral alliances at the heart of the security framework of the region. China prefers the type of relationship that it has with Russia, as I have described. It is my hope that a middle ground can be found in the concept of security pluralism, a concept newly favored by both Washington and Beijing.

This concept inherently implies inclusiveness, the incorporation in the framework of nations as diverse as China and Mongolia. Furthermore, the contingencies that this new security framework is likely to face will probably include non-traditional threats to regional security and other unpredictable crises. I see here a role for Ulaanbaatar not only as a neutral capital and mediator but also as a component of peacekeeping forces and in other areas well suited to the strengths of Mongolia's diplomatic corps and military forces. The United States views Mongolia as a valuable partner in Northeast Asian security, especially as we face the difficult problems of a changing security framework in this region. 